Energy and Thermofluids Engineering

\title{
Development and performance analysis of a PCM based cooling fan for hot climate of Bangladesh
}

\author{
Md. Anowar Hossain ${ }^{1 凶}$, I. M. Mahbubul2 ${ }^{2 \bowtie}$, Md. Abdul Aziz², Hasan Mohammad Mostofa Afroz ${ }^{1,2}$, Md. Rashedul \\ Islam ${ }^{1}$, Md. Johirul Islam ${ }^{1}$ \\ ${ }_{1}^{1}$ Department of Mechanical Engineering, Dhaka University of Engineering \& Technology, Gazipur (DUET), Gazipur 1707, Bangladesh
}

2Institute of Energy Engineering (IEE), Dhaka University of Engineering \& Technology, Gazipur (DUET), Gazipur 1707, Bangladesh

\section{Received 5 September 2020 \\ Revised 3 November 2020 \\ Accepted 5 November 2020 \\ Published online: 27 December 2020}

Keywords

Renewable energy

Solar energy

Sustainability

Electric fan

Room cooling

Phase change materials

\begin{abstract}
In hot climatic regions, some kind of cooling system is necessary to avoid warmth and humidity. Many of the available cooling systems are not economic and sustainable. In this study, sustainable and feasible space/room cooling systems have been experimentally analyzed. A solar operated cooling system with two options have been designed and their performances are compared. Phase Change Material (PCM) is proposed to store thermal energy instead of a costly battery. A 1200-watt compressor and fin-type condenser are used to construct the vapor compression system. When the incoming air is passed through the cooling coil, it gets cool. For this cooling coil, 50 feet copper tube is used. The front side copper tube diameter of the fan is $3 / 8$ inch and the backside tube diameter is $1 / 2$ inch. It took about 35 minutes and 5 minutes to minimize the room temperature at the desired level in the case of the stand fan and duct fan, respectively. Furthermore, the stand fan and duct fan systems reduced $3{ }^{\circ} \mathrm{C}$ and $6{ }^{\circ} \mathrm{C}$ of the outside temperature, respectively.
\end{abstract}

(c) 2020 The authors. Published by Alwaha Scientific Publishing Services, ASPS. This is an open access article under the CC BY license.

\section{Introduction}

Now a day, air cooling is obtained by using evaporative coolers, fans, dehumidifiers, and air conditioners (A/C). Most of the above systems required huge capital and operating costs as well as electricity is required to operate these systems. To generate electricity, non-conventional energy sources or fossil fuels are used, which are responsible for environmental pollution and global warming. Even, many parts of the world have a scarcity of electricity. As an alternative, some researchers have developed off-grid solar fan and A/C. Such systems require many PV panels to provide sufficient electricity, which is still expensive. Where the energy storage system (battery) is the most expensive part.
Bangladesh is a middle income and developing nation. The electricity demand is increasing day by day although, the government is working on the development of electricity. Electrification of new regions, industrial growth, installation of rapidly growing technological-, telecommunication-, and electronic devices, increasing demand for cooling, and comforts are some major issues of the electricity demand rising. Due to global warming, the comfortable weather of Bangladesh is going to be changed. The weather in Bangladesh was famous for six seasons where only about two months was summer. Electrical fans (ceiling, stand, and table types) are vastly used in Bangladesh for cooling and comfort from temperature and humidity. In recent years, the summer

$\llbracket$ Corresponding author. E-mail address: anowar96me@gmail.com (Prof. M. A. Hossain) ; immahbubul@gmail.com (Dr. I. M. Mahbubul) 
period is prolonging along with the increase of temperature feelings like extreme hot. Some of the probable reasons are deforestation, industrialization, modern civilization as well as many other things. Now a day, cooling by electrical fans can not provide enough comfort. Therefore, the use of air conditioning units is increasing mostly in commercial buildings. Most citizens cannot afford the initial and operating cost of air conditioning systems.

Since air conditioning is not applicable in most of the cases in Bangladesh and temperature is going to be extreme. Therefore, some kind of alternative and affordable technology is required. There are many new proposed and feasible cooling technologies available in the literature. Absorption cooling systems (Avanessian and Ameri 2014; Borge-Diez et al. 2012), $\mathrm{CO}_{2} / \mathrm{NH}_{3}$ cascade cooling systems (Aminyavari et al. 2014; Rezayan and Behbahaninia 2011), ejector cascade cooling systems (Dokandari et al. 2014), compression absorption cascade refrigeration systems (Jain et al. 2015), ejector cooling systems (Besagni et al. 2016; Tashtoush et al. 2015), desiccant cooling systems (Beccali et al. 2012; Guidara et al. 2013), solar-driven hybrid absorption systems (Khan et al. 2016; Ibrahim et al. 2017), energy storage cooling systems (Noro et al. 2014; Chidambaram et al. 2011) are some of the examples of advanced cooling systems. However, most of the above cooling systems are suitable for large scales and required a lot of initial cost for many of these (of course not all the above are costly; for example, a desiccant cooling system is comparatively cheaper) (Gupta et al. 2016). A review on different types of thermal cooling systems (absorption, adsorption, desiccant systems using solids and liquids, ejector-compression systems, and hybrid systems) is compiled by Best and Rivera 2015.

Further, the electricity price is increasing. Unavoidable emissions are unexpected results during the conversion of energy, especially in fuel-based conversion systems. Further, a lot of heat losses are observed since the heat to power conversion efficiency is very low in the case of a fuel-based system. Moreover, fossil fuels are limited and will be finished. The natural replenishment of fossil fuels takes hundreds to millions of years to convert as an energy source. Hence, there need some alternative electricity production sources and systems.

The Sun is the prime source of energy in the world (Kalogirou 2004). Traditionally, mankind, animals, and plants are benefitted from the heat and light of the Sun
(Mahbubul 2019). Recent technological developments established that energy could be generated by converting the light and heat of the Sun. Water heating, space heating and cooling, and power generation could be done by using the heat of the Sun (Mahbubul et al. 2018). Different types of solar collectors are used for water heating and space heating and cooling. In the case of power generation from the heat of the Sun, the technologies are termed concentrated solar power (CSP). Electricity could be generated from the light of the Sun by using different types of solar panels and the technology is called photovoltaic (PV) conversion. Electricity generation by using the heat of the Sun (CSP technologies) are applicable for large scale plants. Whereas, PV technologies (solar panels) could be used to generate any type of plants (starting from milliwatts to gigawatts). Due to the technological advancements (thanks go to many researchers and policymakers), the electricity generation cost by solar PV systems is the cheapest in many parts of the world. Only the challenge and limitation is the unavailability of the Sun during nights and lower production yield during cloudy days. Therefore, some kind of energy storage system is required to get a continuous supply of electricity generated from the solar PV systems. The electrochemical (battery) systems are still costly energy storage items. Different types of phase change materials (PCM) are suitable to store thermal energy and comparatively cheaper (Sharma et al. 2009).

Since long-term solar radiation records prove that photovoltaic technology is very much suitable to generate renewable energy in Bangladesh (Iqbal et al. 2018). Therefore, by considering all the above things, in the present study, a PCM based solar power air cooling system is designed and experimentally analyzed. A simple proposal is to put a copper coil on the outside of the frame of the conventional fan and linking the coil to the condenser and evaporation units can improve the cooling effect to provide enough comfort. The modification of the solar power cooling fan is simple. When the solar power is available then the compressor compressed refrigerant and it passes through the condenser and evaporator. The circulated air will be passed through over the cooling coil which is mounted on the frame of a conventional fan and become cool after condensing some moisture on the cooling coil. PCM can provide sufficient cooling effect consequently this is environment friendly and consume less energy. Since a renewable source of energy (solar) is 
proposed to use to run the system; therefore, the operating cost will be near zero. The overall objective of the study is to develop a sustainable cooling system at an affordable fixed cost with zero operating costs. Further, this study includes the design and selection of a cooling system for the application of room/space cooling along with a thermal battery (PCM) box with an evaporative coil. Performance analysis as the variation of the temperatures with time for a stand fan (without fin) and a duct fan (with fin) are measured and compared. Hopefully, this study will shed light on the research area of solar operated cooling options. Further modification can create opportunities for such commercial products.

\section{Methodology}

\subsection{Solar unit}

There are four units in the present study. There are solar panel unit, condensing unit, thermal energy storage (TES) unit, and cooling unit. The list of the materials is shown as a flow chart in Fig. 1.
The open-circuit voltage of each panel is 41 volts. When load applied to the panel then the voltage dropped and the available output is about 37 to 24 volt. That's why two panels are connected in parallel (as shown in Fig. 2) because the voltage is the same in parallel connection but the current increase. Each panel ratted power ratting is 320 Watt.

The charge controller uses to control the charge level of the storage battery simultaneously supply to the load. Power Com Lumiax TM Max Series Solar Charge Controller model PCM-SCC 30; Capacity 12/24v, 30A was used (as shown in Fig. 3). There are three terminals in this charge controller one is input from the solar panel, others are output to the storage battery, and output to the load. There is a separate lighting system to indicate the different levels of battery and solar panel output.

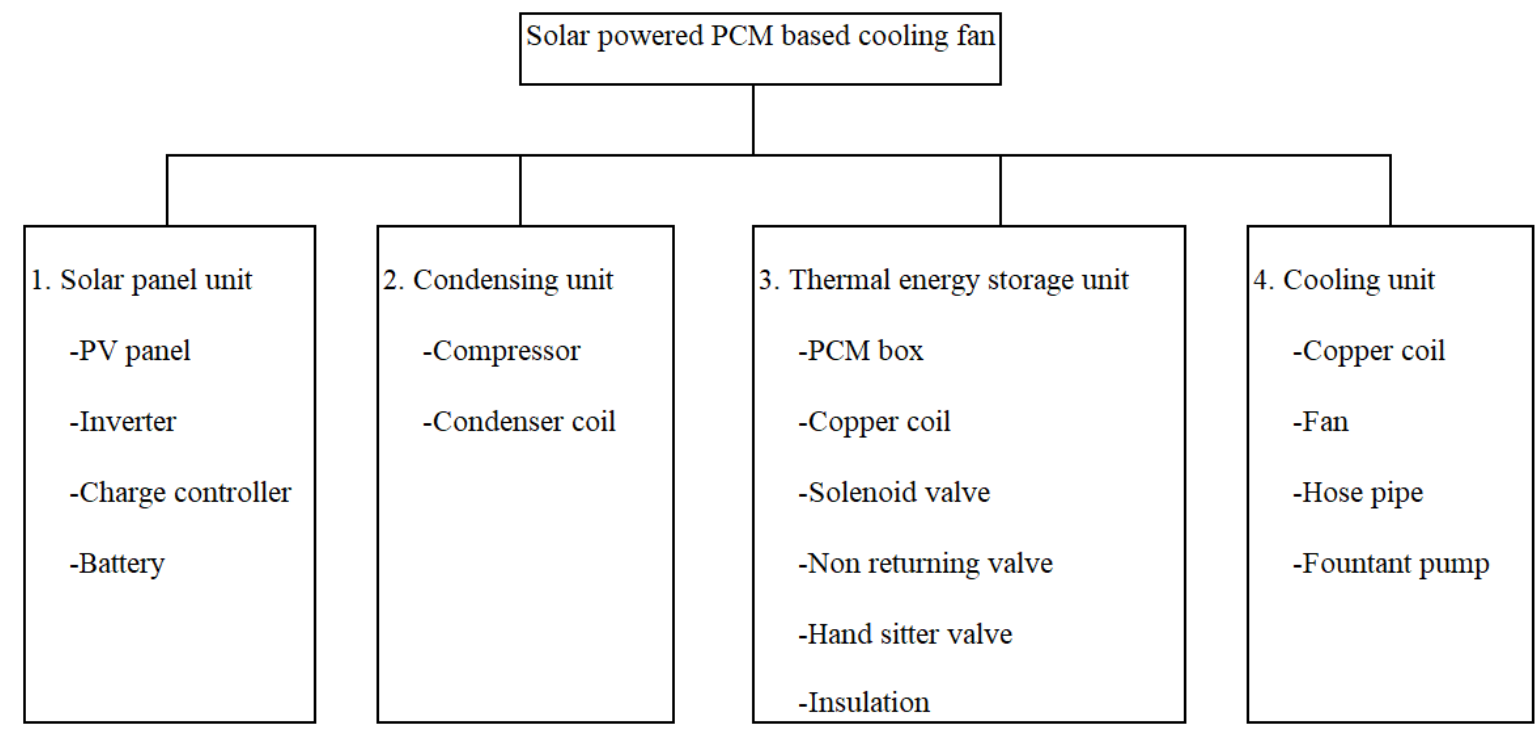

Fig. 1. Components of solar-powered PCM based cooling fan.

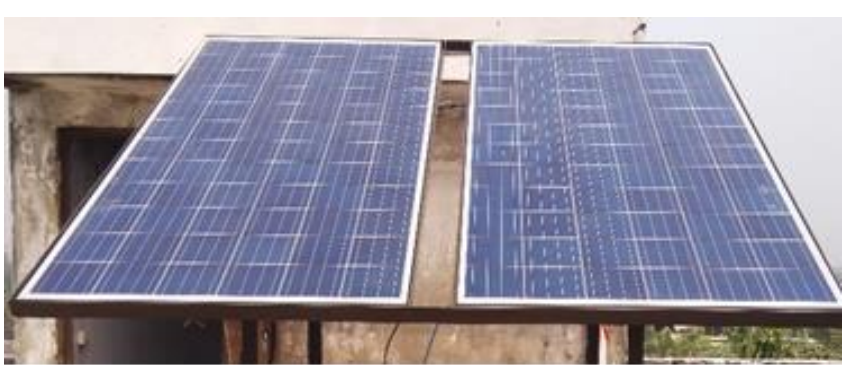

Fig. 2. Solar panels.

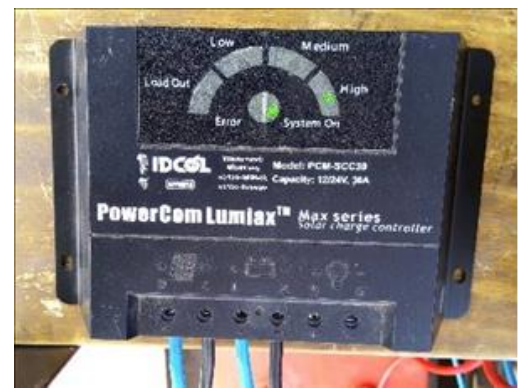

Fig. 3. Charge controller. 


\subsection{Experimental setup}

In the present study, a solar-powered vapor compression refrigeration system is used to produce ice or solidified (charge) PCM. A solar operated fountain pump is then used to circulate the secondary low-temperature fluid through the cooling coil situated at the backside of a solarpowered fan. The temperature of the secondary fluid maintains at a low temperature by mixing with Ice or solid PCM in a certain proportion. To maintain constant low temperature and run the system automatically, a thermostat operated solenoid valve is used.

During the night or when sunshine is not available then the solid (charged) PCM provides the necessary cooling effect by absorbing a large amount of latent heat from the secondary fluid. The schematic diagram of the whole system is shown in Fig. 4. At first copper tube is wounded on the front- and back-sides of the stand fan as shown in Fig. 5. The diameter of the front tube is $3 / 8$ inch and the back tube is $1 / 2$-inch, the total length of the tube is 50 feet. The whole coil is wounded on the casing on the fan and attached with cable ties. The tubes are spaced equally and try to maintain minimum spacing so that air can get more contact with the tube.

After winding the coil over the fan casing, the compressor was placed at the exact position on the outdoor unit as shown in Fig. 6.

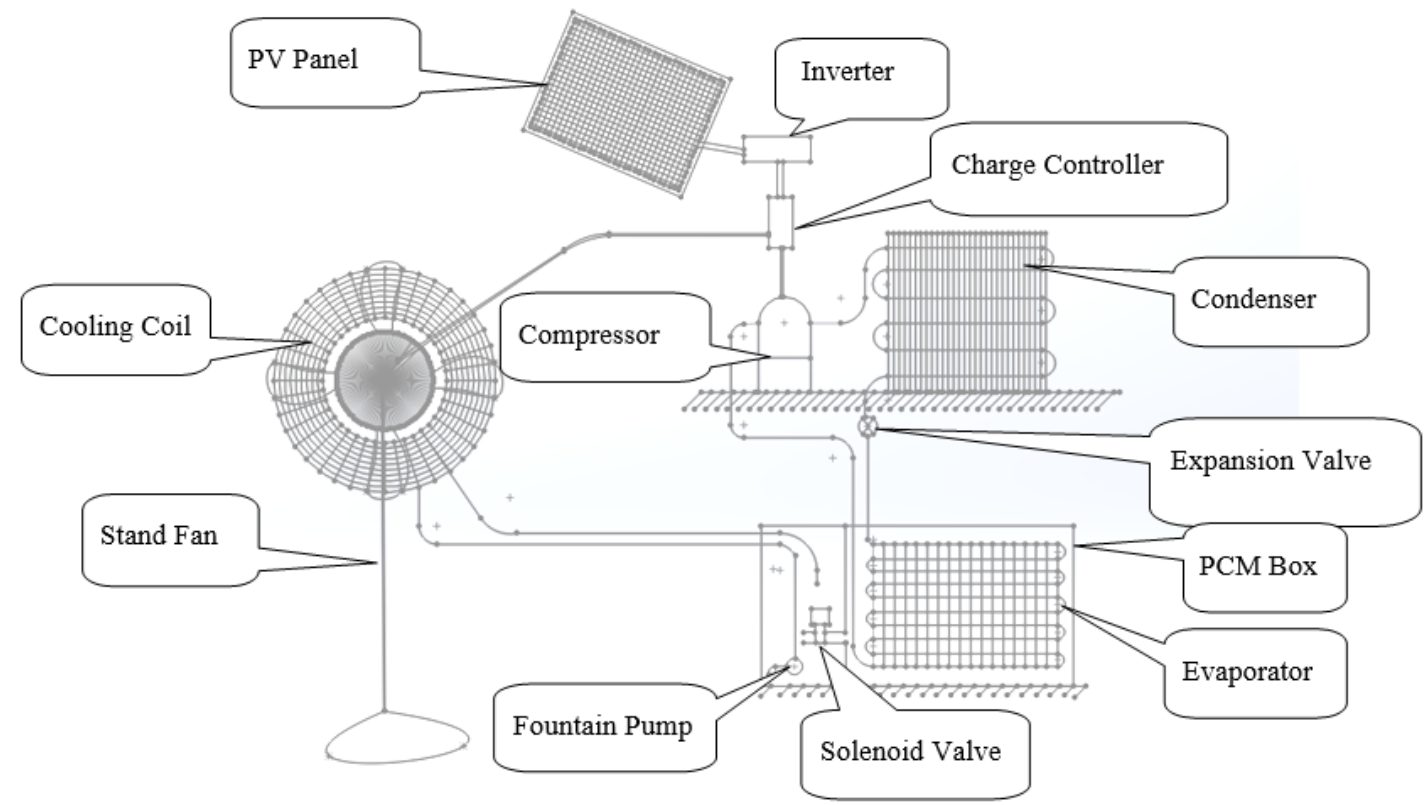

Fig. 4. Schematic diagram of a solar-powered PCM based cooling fan.

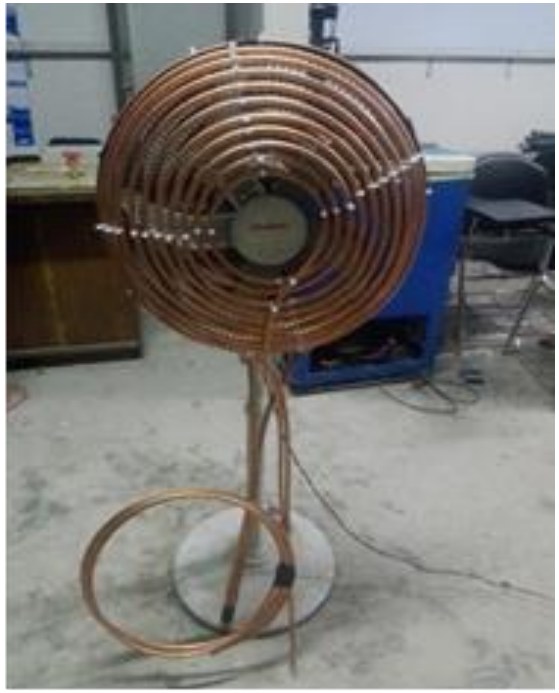

Fig. 5. Copper tube winding on the fan.

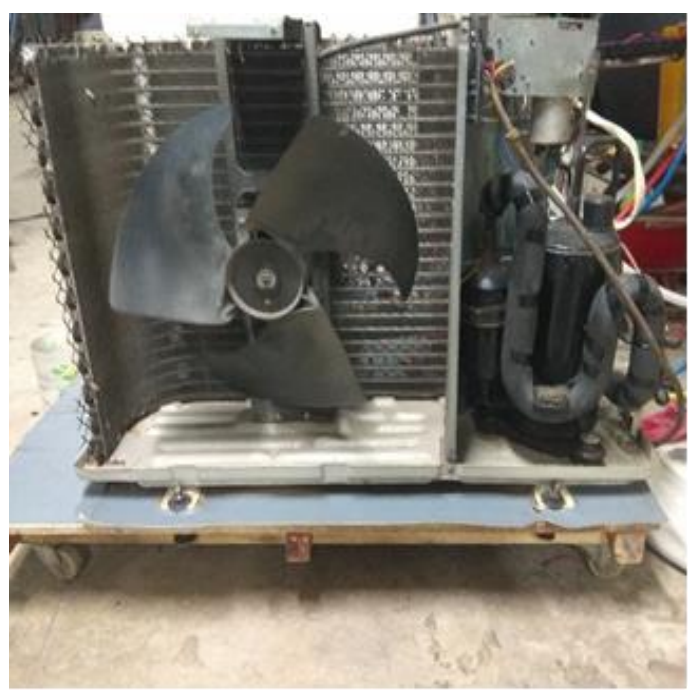

Fig. 6. Condensing unit. 
The other fan setup (duct fan mode) is shown in Fig. 7 as the front- and back-side images of the duct fan with fins. Duct fan mode means that the fan is running with the cooling coil (copper tube) and fins. Brazing was used to ensure the proper connection of different joining as shown in Fig. 8.

Valve setting is an important part. If the valves are placed incorrectly, then the refrigerant loss will be increased. That's why the hand sitter valve, non-returning valve, and solenoid valve are placed in the exact position according to the design. Different valves setting are shown in Fig. 9. The PCM box is the most important part of the study. It is produced the required ice and supplies a cooling effect on the fan. A PCM box contains a copper tube, solenoid valve, fountain pump, hose pipe, and phase change material. In this study, water was used as the PCM (where water changes its phase to ice and vice versa). The copper tube was placed on the PCM box to produce ice. It was connected to the condensing unit, and refrigerant flows through the copper tube. Fountain pump placed beside the box to supply cooling water on the fan. The solenoid valve setting is inside the box, and the hose pipe is connected to the stand fan.
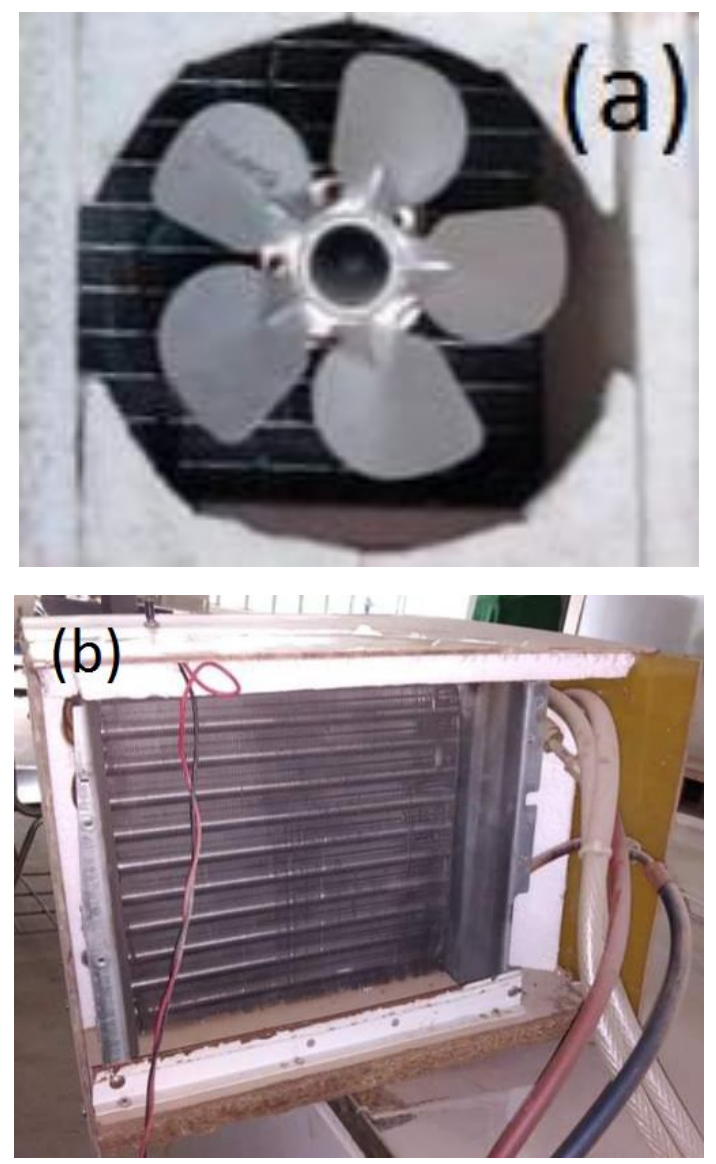

Fig. 7. Duct fan with fins: (a) front side and (b) backside.

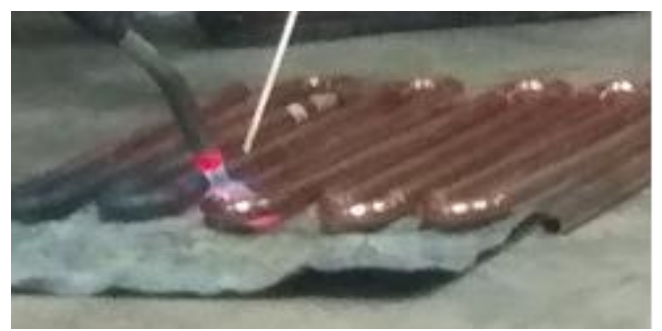

Fig. 8. Brazing.

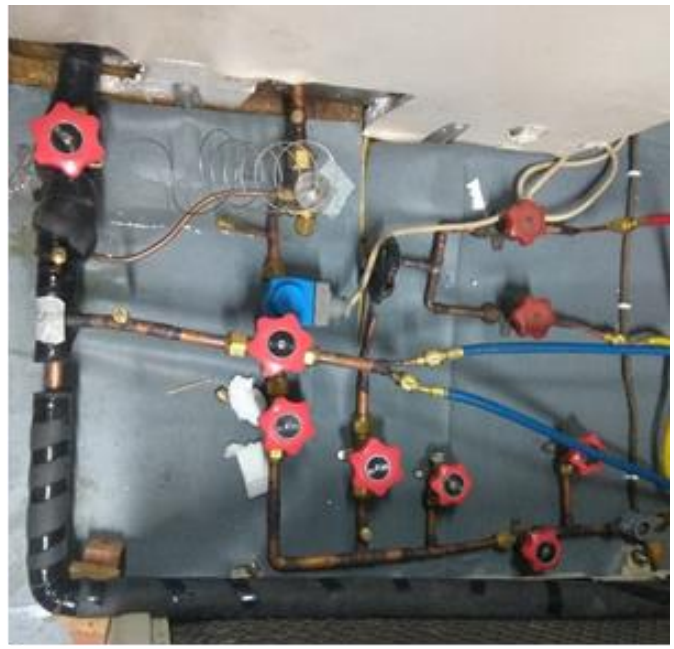

Fig. 9. Valve setting.

Fig. 10 shows the PCM box sets. After completing all procedures according to the design, the refrigerant was charged. In this study, refrigerant R-22 was used. Before charging the refrigerant the system was evacuated by a vacuum pump then the refrigerant tank is connected to the compressor by hose pipe. The full setup is shown in Fig. 11. After charging, the refrigerant hose pipe is disconnected from the compressor charging line. After completion of all manufacturing, it was tested in different ways. The compressor was run and checked the temperature of the cooling coil. All of the possible connections were carefully checked by different leak testing methods. After completing all testing, the experiments were successfully conducted.

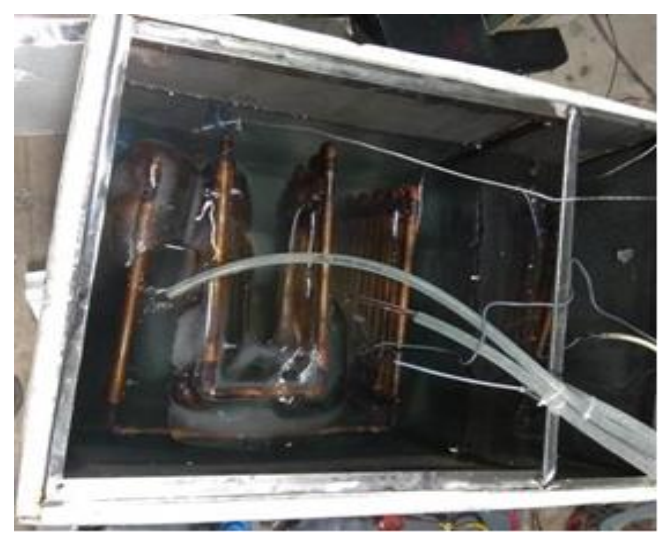

Fig. 10. PCM Box. 


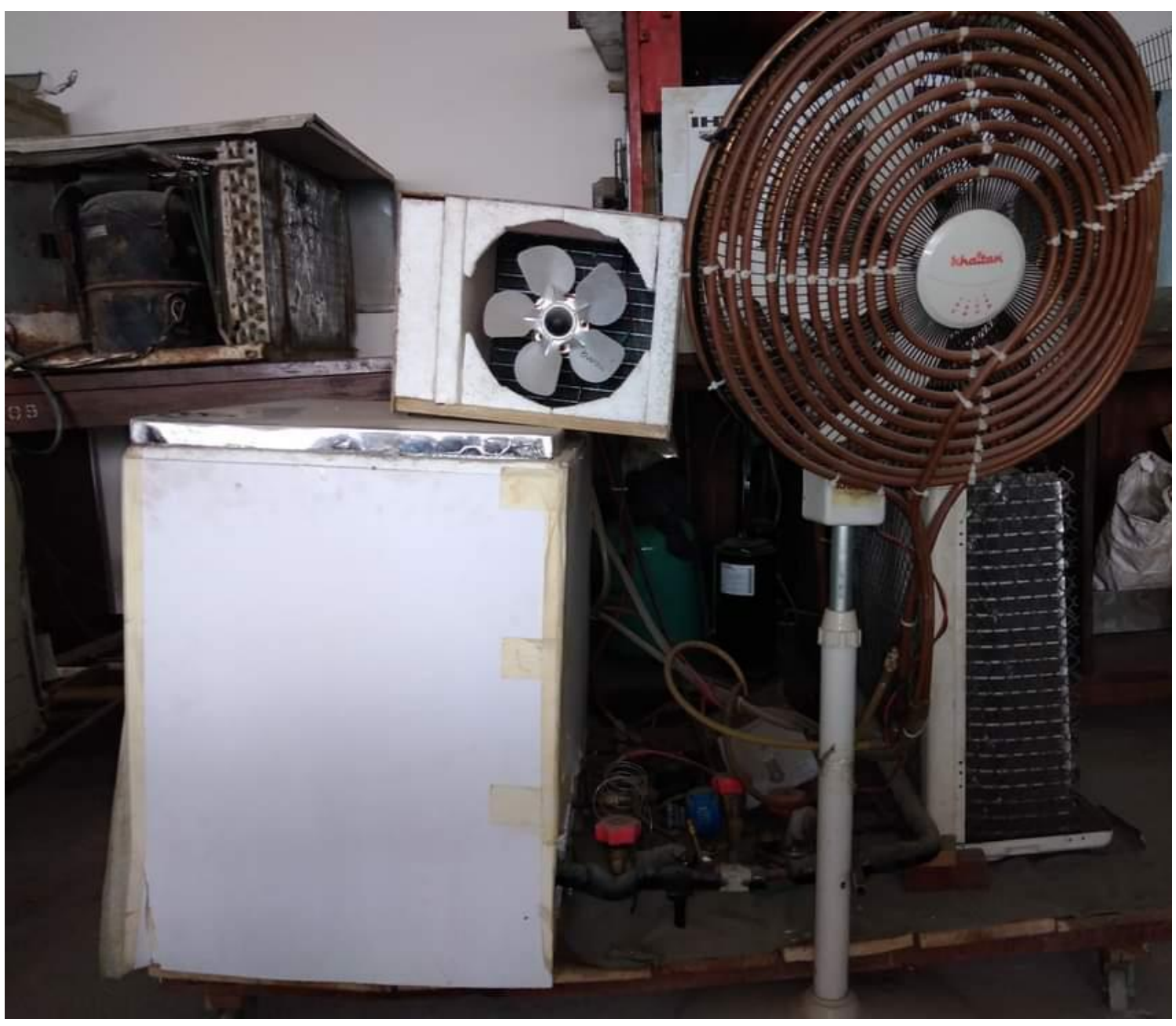

Fig. 11. Complete experimental setup.

\section{Results and Discussion}

\subsection{Rated configuration of the solar panels}

The rated configurations and measured data are shown in Tables 1 and 2, respectively.

\subsection{Relation between light and output power}

PV solar cells directly produced electrical power when sunlight (direct and/or diffuse) falls upon them. In general, power output from the solar panel is proportional to the sunlight. Although there are some variables of weather conditions like cloud, temperature, dust, moisture, and humidity affect the performance of solar panel output.

The maximum power output from the solar panels was observed 457.46 Watt at time 13:00 hours.

Therefore, efficiency $=(457.46 / 640) \times 100=71.47 \%$.

The open-circuit voltage of this panel was 40.9 volt (Max). The voltage which is getting from the panel at no-load condition is called open-circuit voltage. The short circuit current of this panel was observed to be 18.01 Ampere
(Max) at two panels parallel condition. Measured quantities of current at short circuit condition of the panel is called short circuit current.

Fig. 12 shows the relation between voltage and current with time. It can be seen in the figure that the maximum voltage of $24.80 \mathrm{~V}$ was observed at day time of 14.00 hours and the maximum current was observed to be $17.80 \mathrm{Amp}$ at 13.00 hours. Sunlight intensity was much higher at that time.

Table 1. Rated configuration data table.

\begin{tabular}{ll}
\hline Properties & Quantity \\
\hline Rated STC power (Pmpp) & $320 \mathrm{~W}$ \\
Rated Voltage (Vmpp) & $37.18 \mathrm{~V}$ \\
Rated Current (Impp) & $8.61 \mathrm{~A}$ \\
Series Fuse (A) & $15 \mathrm{~A}$ \\
Max system Voltage IEC 61730 & $1000 \mathrm{~V}$ \\
Power Tolerance & $0,+3 \%$ \\
Open circuit Voltage (Voc) & 45.91 \\
Short circuit current (Isc) & $9.12 \mathrm{~A}$ \\
\hline
\end{tabular}


Table 2. Measured data table.

\begin{tabular}{|c|c|c|c|c|c|c|}
\hline $\begin{array}{l}\text { Date } \\
\text { \& Time }\end{array}$ & $\begin{array}{l}\text { Atmospheric } \\
\text { Temperature }\left({ }^{\circ} \mathrm{C}\right)\end{array}$ & $\begin{array}{l}\text { PV Panel } \\
\text { Output, V (V) }\end{array}$ & $\begin{array}{l}\text { PV Panel } \\
\text { Output, I (A) }\end{array}$ & $\begin{array}{l}\text { Battery Charging, } \\
\text { V (V) }\end{array}$ & $\begin{array}{l}\text { Battery Charging, } \\
\text { I (A) }\end{array}$ & $\begin{array}{l}\text { With Solar "Yes" } \\
\text { Without Solar "No" }\end{array}$ \\
\hline \multicolumn{7}{|l|}{$08-03-18$} \\
\hline 2:30 PM & 37.50 & 26.00 & 15.50 & 25.85 & 15.50 & Yes \\
\hline 3:30 PM & 35.00 & 25.41 & 11.50 & 25.32 & 11.60 & Yes \\
\hline 4:30 PM & 33.30 & 24.66 & 6.50 & 24.62 & 6.50 & Yes \\
\hline 5:30 PM & 31.90 & 24.00 & 2.80 & 23.90 & 2.80 & Yes \\
\hline 6:00 PM & 23.00 & 23.00 & 0.00 & 24.00 & 0.00 & No \\
\hline 7:00 PM & 23.00 & 6.50 & 0.00 & 24.00 & 0.00 & No \\
\hline 8:00 PM & 22.30 & 6.40 & 0.00 & 24.00 & 0.00 & No \\
\hline 9:00 PM & 22.00 & 6.40 & 0.00 & 23.90 & 0.00 & No \\
\hline 10:00 PM & 21.90 & 6.30 & 0.00 & 23.60 & 0.00 & No \\
\hline 11:00 PM & 21.40 & 6.30 & 0.00 & 23.40 & 0.00 & No \\
\hline 12:00 PM & 21.00 & 6.30 & 0.00 & 23.00 & 0.00 & No \\
\hline \multicolumn{7}{|l|}{ 09-03-18 } \\
\hline 09:00 AM & 31.60 & 25.40 & 8.65 & 24.40 & 8.65 & Yes \\
\hline 10:00 AM & 32.40 & 25.40 & 13.70 & 24.40 & 13.70 & Yes \\
\hline 11:00 AM & 33.70 & 25.60 & 14.20 & 25.40 & 14.20 & Yes \\
\hline 12:00 PM & 35.00 & 25.70 & 17.60 & 25.60 & 17.20 & Yes \\
\hline 1:00 PM & 36.00 & 25.70 & 17.80 & 25.60 & 17.80 & Yes \\
\hline 2:00 PM & 36.00 & 25.80 & 15.70 & 25.60 & 15.60 & Yes \\
\hline 3:00 PM & 34.00 & 25.20 & 11.90 & 25.00 & 11.90 & Yes \\
\hline 4:00 PM & 33.00 & 24.44 & 9.70 & 24.00 & 9.60 & Yes \\
\hline 5:00 PM & 28.20 & 24.00 & 5.70 & 23.90 & 5.70 & Yes \\
\hline 6:00 PM & 23.00 & 6.00 & 0.00 & 23.00 & 0.00 & No \\
\hline 7:00 PM & 22.00 & 6.00 & 0.00 & 23.00 & 0.00 & No \\
\hline 8:00 PM & 21.90 & 6.00 & 0.00 & 22.90 & 0.00 & No \\
\hline 9:00 PM & 21.60 & 6.00 & 0.00 & 22.60 & 0.00 & No \\
\hline 10:00 PM & 21.20 & 5.40 & 0.00 & 22.40 & 0.00 & No \\
\hline 11:00 PM & 21.10 & 5.40 & 0.00 & 22.28 & 0.00 & No \\
\hline $12: 00 \mathrm{AM}$ & 21.09 & 5.40 & 0.00 & 22.20 & 0.00 & No \\
\hline $12: 15$ AM & 21.00 & 5.40 & 0.00 & 21.50 & 0.00 & No \\
\hline $10-03-18$ & Cloudy & & & & & \\
\hline 10:00 AM & 30.40 & 25.05 & 7.00 & 24.40 & 7.00 & Yes \\
\hline
\end{tabular}

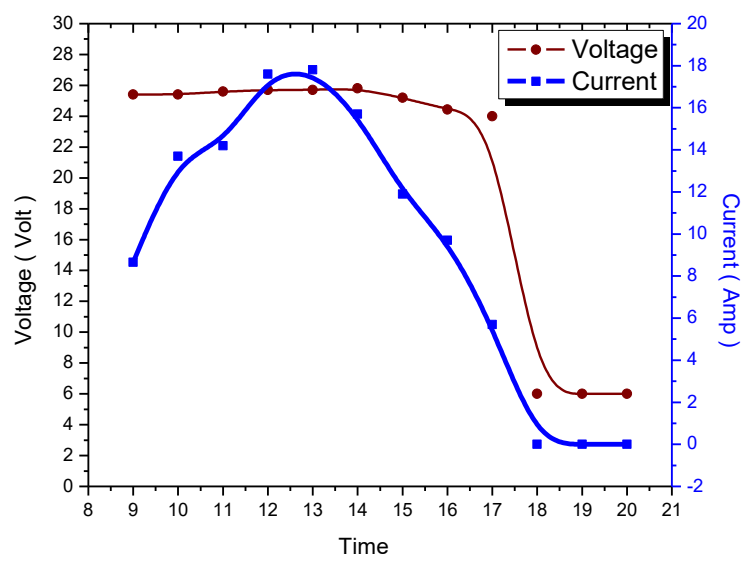

Fig. 12. Time vs voltage and current without cloudy condition.

Voltage and current at different periods of a day in the cloudy condition are shown in Fig. 13. In Fig. 13 at time 12:30 PM, the current goes down because of cloudy conditions. The current shown in the graph at time $10 \mathrm{AM}$ and 12:30 PM become the lowest. At the end of the day when sunlight was absent, then the current of the system became zero but some voltage is available which is not useful.

\subsection{Performance of a stand fan (without fin)}

Stand fan modes mean that the fan is running with the cooling coil but this coil not using any kind of fins. The temperature of the air and cooling water is thrown by the fan at a distance of 0.5 meters in this mode. Variation of temperature with time of a stand fan (without fin) is mentioned in Table 3.

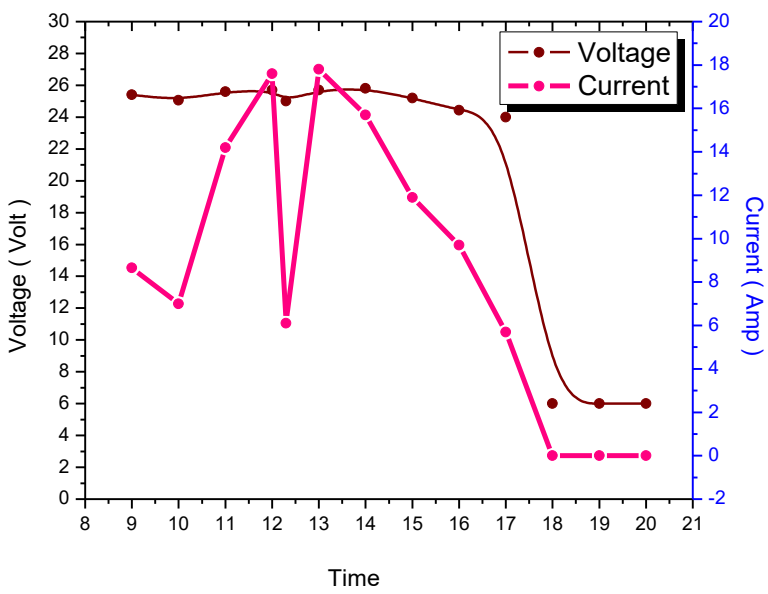

Fig. 13. Voltage and current at the cloudy condition. 
Table 3. The different measured values of the stand fan (without fin).

\begin{tabular}{ccccccc}
\hline $\begin{array}{c}\text { Time } \\
(\mathrm{sec})\end{array}$ & $\begin{array}{c}\text { Water flow } \\
\text { rates }(\mathrm{L} / \mathrm{min})\end{array}$ & $\begin{array}{c}\text { Cooling } \\
\text { water in } \\
\left({ }^{\circ} \mathrm{C}\right)\end{array}$ & $\begin{array}{c}\text { Cooling } \\
\text { water out } \\
\left({ }^{\circ} \mathrm{C}\right)\end{array}$ & $\begin{array}{c}\text { Air } \\
\text { velocity } \\
(\mathrm{m} / \mathrm{s})\end{array}$ & $\begin{array}{c}\text { Air in } \\
\left({ }^{\circ} \mathrm{C}\right)\end{array}$ & $\begin{array}{c}\text { Air out } \\
\left({ }^{\circ} \mathrm{C}\right)\end{array}$ \\
\hline 0 & 4 & 7.1 & 11.0 & 2.8 & 28 & 27.5 \\
5 & 4 & 7.1 & 11.0 & 2.8 & 28 & 27.5 \\
10 & 4 & 6.5 & 11.0 & 2.8 & 28 & 27.2 \\
15 & 4 & 6.0 & 10.6 & 2.8 & 28 & 27.0 \\
20 & 4 & 6.0 & 11.0 & 2.8 & 29 & 26.8 \\
25 & 4 & 5.5 & 11.0 & 2.8 & 29 & 26.3 \\
30 & 4 & 5.0 & 11.3 & 2.8 & 29 & 26.3 \\
35 & 4 & 5.0 & 11.3 & 2.8 & 29 & 26.3 \\
\hline
\end{tabular}

\subsection{Performance of a duct fan (with fin)}

Duct fan mode means that the fan is running with the cooling coil and fins. In this mode, we measured the temperature of the air and cooling water thrown by the fan at a distance of 0.5 meters. Variation of temperature with time of a stand fan (with fin) is mentioned in Table 4.

\subsection{Comparison between two fans}

The observed performances of the two modes were compared and depicted in Fig. 14. It can be seen in Fig. 14 that the best performance was observed for the duct fan (with fin). This system (duct fan) has a quick cooling capacity; therefore, the maximum reduced air temperature was observed in this case.

\subsection{Bypass factor}

Bypass factor $=\frac{\text { Air temp. after cooling }- \text { Cooling coil temp. }}{\text { Air temp } \text {. before cooling }- \text { Cooling coil temp. } .}$

Therefore, bypass factor for stand fan $=\frac{26.86-9}{28.5-9}=0.916$

Bypass factor for duct fan (with fin) $=\frac{23-7.5}{29-7.5}=0.720$

Table 4. The different measured values of the duct fan (with fin).

\begin{tabular}{ccccccc}
\hline $\begin{array}{r}\text { Time } \\
(\mathrm{sec})\end{array}$ & $\begin{array}{c}\text { Water flow } \\
\text { rates } \\
(\mathrm{L} / \mathrm{min})\end{array}$ & $\begin{array}{c}\text { Cooling } \\
\text { water in } \\
\left({ }^{\circ} \mathrm{C}\right)\end{array}$ & $\begin{array}{c}\text { Cooling } \\
\text { water out } \\
\left({ }^{\circ} \mathrm{C}\right)\end{array}$ & $\begin{array}{c}\text { Air } \\
\text { velocity } \\
(\mathrm{m} / \mathrm{s})\end{array}$ & $\begin{array}{c}\text { Air in } \\
\left({ }^{\circ} \mathrm{C}\right)\end{array}$ & $\begin{array}{c}\text { Air out } \\
\left({ }^{\circ} \mathrm{C}\right)\end{array}$ \\
\hline 0 & 2 & 3.0 & 13.0 & 1.9 & 29 & 28.0 \\
1 & 2 & 3.5 & 13.0 & 1.9 & 29 & 27.0 \\
2 & 2 & 4.0 & 13.5 & 1.9 & 29 & 25.6 \\
3 & 2 & 5.0 & 14.0 & 1.9 & 29 & 25.0 \\
4 & 2 & 5.5 & 14.0 & 1.9 & 29 & 24.0 \\
5 & 2 & 6.0 & 15.0 & 1.9 & 29 & 23.0 \\
\hline
\end{tabular}

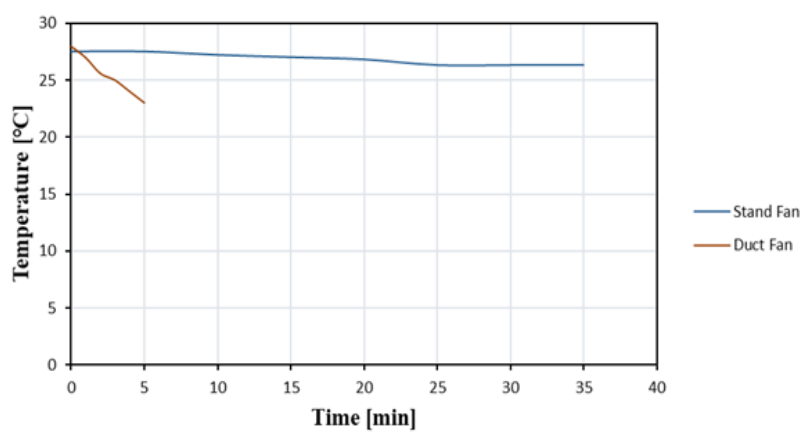

Fig. 14. Comparison between two fans.

\section{Conclusions}

A sustainable room cooling system operated by solar power with a PCM based storage is proposed with two output options. Their cooling rate and temperature were measured and analyzed. It has been observed that temperature decreases to the desired level within 35 minutes and 5 minutes in the case of stand fan and duct fan, respectively. Whereas, the temperature was reduced in comparison to the room temperature of approximately $3{ }^{\circ} \mathrm{C}$ and $6{ }^{\circ} \mathrm{C}$ for stand fan and duct fan, respectively. The cooling effect was not significant in the stand fan because of having a higher bypass factor. The bypass factor of the system was higher due to the single row cooling coil and not to have any fin in the cooling coil. The bypass factor of the stand fan was $91.6 \%$ and the duct fan is $72.6 \%$. That's why the temperature of the system was not decreased much. The bypass factor can be reduced by using multiplerow cooling coils and attaching fins with the cooling coil. Another reason is that most of the air is blocked in the path of flow due to the close arrangement of the copper tubes.

Optimization of fin and cooling coil geometries (length, diameter, area, and orientation) could be analyzed as a further extension of the present work. Moreover, cost comparison and feasibility study is another recommendation for future study.

\section{Disclosures}

Free Access to this article is sponsored by EURL BADYLEC.

\section{Acknowledgments}

This work is supported in part by the Grant-in-Aid for research project 2017-2018 to be conducted by the teachers of DUET under the University Grants Commission (UGC) of Bangladesh. Prof. Dr. Md. Anowar Hossain 
expresses sincere gratitude to the corresponding committee of DUET grant-in-Aid. Prof. Anowar also acknowledges all teachers and staff of the Department of Mechanical Engineering and Institute of Energy Engineering of DUET for their cordial support.

\section{References}

Aminyavari, M., B. Najafi, A. Shirazi, F. Rinaldi (2014) Exergetic, economic and environmental (3E) analyses, and multiobjective optimization of a $\mathrm{CO}_{2} / \mathrm{NH}_{3}$ cascade refrigeration system. Applied Thermal Engineering 65(1-2): 42-50.

Avanessian, T., M. Ameri (2014) Energy, exergy, and economic analysis of single and double effect $\mathrm{LiBr}-\mathrm{H}_{2} \mathrm{O}$ absorption chillers. Energy and Buildings 73: 26-36.

Beccali, M., P. Finocchiaro, B. Nocke (2012) Energy performance evaluation of a demo solar desiccant cooling system with heat recovery for the regeneration of the adsorption material. Renewable Energy 44: 40-52.

Besagni, G., R. Mereu, F. Inzoli (2016) Ejector refrigeration: A comprehensive review. Renewable and Sustainable Energy Reviews 53: 373-407.

Best, R., W. Rivera (2015) A review of thermal cooling systems. Applied Thermal Engineering 75: 1162-1175.

Borge-Diez, D., A. Colmenar-Santos, C. Pérez-Molina, M. CastroGil (2012) Experimental validation of a fully solar-driven triple-state absorption system in small residential buildings. Energy and Buildings 55: 227-237.

Chidambaram, L.A., A.S. Ramana, G. Kamaraj, R. Velraj (2011) Review of solar cooling methods and thermal storage options. Renewable and Sustainable Energy Reviews 15(6): 3220-3228.

Dokandari, D. A., A.S. Hagh, S.M.S. Mahmoudi (2014) Thermodynamic investigation and optimization of novel ejector-expansion $\mathrm{CO}_{2} / \mathrm{NH}_{3}$ cascade refrigeration cycles (novel $\mathrm{CO}_{2} / \mathrm{NH}_{3}$ cycle). International Journal of Refrigeration 46: 26-36.

Guidara, Z., M. Elleuch, H.B. Bacha (2013) New solid desiccant solar air conditioning unit in Tunisia: Design and simulation study. Applied Thermal Engineering 58(1-2): 656-663.

Gupta, A., Y. Anand, S.K. Tyagi, S. Anand (2016) Economic and thermodynamic study of different cooling options: A review. Renewable and Sustainable Energy Reviews 62: 164-194.
Ibrahim, N.I., M.M.A. Khan, I.M. Mahbubul, R. Saidur, F.A. AlSulaiman (2017) Experimental testing of the performance of a solar absorption cooling system assisted with ice-storage for an office space. Energy Conversion and Management 148: 1399-1408.

Iqbal, A., S. Chowdhury, M. H. Srijan, M. U. Faruq, A. Rahman, A. Azad (2018) Performance and feasibility analysis of an AC compressor freezer with a swapped DC compressor for optimum solar use - A complete off-grid solution ensuring food security. Proceedings of the 2018 IEEE Symposium on Computer Applications \& Industrial Electronics (ISCAIE), Penang, Malaysia, pp. 65-70.

Jain, V., G. Sachdeva, S.S. Kachhwaha (2015) NLP model based thermoeconomic optimization of vapor compressionabsorption cascaded refrigeration system. Energy Conversion and Management 93: 49-62.

Kalogirou, S.A. (2004) Solar thermal collectors and applications. Progress in Energy and Combustion Science 30(3): 231-295.

Khan, M.M.A., N.I. Ibrahim, R. Saidur, I.M. Mahbubul, F.A. AlSulaiman (2016) Performance assessment of a solar powered ammonia-water absorption refrigeration system with storage units. Energy Conversion and Management 126: 316-328.

Mahbubul, I.M. (2019) Preparation, Characterization, Properties and Application of Nanofluid. William Andrew Publishing.

Mahbubul, I.M., M.M.A. Khan, N.I. Ibrahim, H.M. Ali, F.A. AlSulaiman, R. Saidur (2018), Carbon nanotube nanofluid in enhancing the efficiency of evacuated tube solar collector. Renewable Energy 121: 36-44.

Noro, M., R.M. Lazzarin, F. Busato (2014) Solar cooling and heating plants: An energy and economic analysis of liquid sensible vs phase change material (PCM) heat storage. International Journal of Refrigeration 39: 104-116.

Rezayan, O., A. Behbahaninia (2011) Thermoeconomic optimization and exergy analysis of $\mathrm{CO}_{2} / \mathrm{NH}_{3}$ cascade refrigeration systems. Energy 36(2): 888-895.

Sharma, A., V.V. Tyagi, C.R. Chen, D. Buddhi (2009) Review on thermal energy storage with phase change materials and applications. Renewable and Sustainable Energy Reviews 13(2): 318-345.

Tashtoush, B., A. Alshare, S. Al-Rifai (2015) Hourly dynamic simulation of solar ejector cooling system using TRNSYS for Jordanian climate. Energy Conversion and Management 100: 288-299. 